\title{
Analysis of bioactive compounds in umbu (Spondias tuberosa) by application of edible coating based on Chlorella sp during storage
}

\author{
Albert Einstein Mathias de Medeiros TEODOSIO ${ }^{1 *}$ (D), Railene Hérica Carlos Rocha ARAÚJO',3, \\ Bárbara Genilze Figueiredo Lima SANTOS ${ }^{1}$, Jéssica Aline LINNÉ, Katia Gomes da SILVA³, \\ Fernando Antônio Lima GOMES ${ }^{1}$, Gleyse Lopes Fernandes de SOUZA ${ }^{1}$, José Franciraldo de LIMA ${ }^{3}$
}

\begin{abstract}
The use of edible coating has been an alternative to maintain the quality of vegetables and prolong their post-harvest life. This study aims to evaluate bioactive compounds in Spondias tuberosa submitted to different coating formulations based on Chlorella sp. associated with the pomegranate seed oil, to establish the one that best maintains post-harvest quality. The experiment was set in a completely randomized design, in a $5 \times 6$ factorial scheme, represented by five coating techniques (T1 = control; T2 = 0.5\% Chlorella sp.; T3 = 1\% Chlorella sp.; T4 = 1.5\% Chlorella sp.; T5 = 2\% Chlorella sp.), using 0.3\% of pomegranate seed oil in coatings, during five evaluation periods $\left(0,1,2,3,4\right.$ and 5 days), stored in BOD incubator at $24 \pm 2{ }^{\circ} \mathrm{C}$ and $85 \pm 5 \% \mathrm{RH}$, with three replicates of ten fruits per plot. Chlorella sp. associated with pomegranate seed oil produced a modified atmosphere around the fruit, retarding the ripening process. Coatings preserved the content of ascorbic acid and phenolic compounds. The treatment containing $2.0 \%$ of Chlorella sp. associated with pomegranate seed oil provided the best maintenance for fruit quality.
\end{abstract}

Keywords: Punica granatum L.; post-harvest; quality of fruits, umbu.

Practical Application: Edible coating based on Chlorella sp. and pomegranate seed oil for post-harvest conservation.

\section{Introduction}

The "umbuzeiro" is an important fruit tree native of Brazilian semi-arid region (Albuquerque et al., 2015; Dias et al., 2019). Fruits are popularly known as "umbu" and they are globose or ovoid, provided with juicy and fiber-free pulp, with sweet-acidulated and very pleasant flavor, which presents bioactive compounds such as carotenoids, vitamin $\mathrm{C}$ and phenolics that confer antioxidant potential (Lorenzi et al., 2015; Ribeiro et al., 2017).

However, the shelf life for Spondias tuberosa is quite short, and fruits present up to a maximum of two to three days at room temperature (Moura et al., 2013). The maturation process is fast and complex, because it is characterized by intense changes in physiological and biochemical parameters, being influenced by the respiration process of fruits that are typically climacteric, which increase ethylene production during ripening, and then it determines rates for chemical changes, such as chlorophyll degradation, enzymatic degradation of the cell wall, changes in contents of sugar and phenolic compounds (Giovannoni et al., 2017; Lima et al., 2018).

In view of the above, there is the need to adopt techniques to maintain and prolong the post-harvest life of S. tuberosa. An alternative to prolong shelf life and maintain the quality of fruits and vegetables during storage, in natura and minimally processed, is the use of edible coatings (Ciolacu et al., 2014;
Maringgal et al., 2020), because they may interfere in respiratory metabolism of fruit, creating a semipermeable barrier against the movement of oxygen, carbon dioxide, moisture and solute, thus controlling the exchanges of moisture, gases and solutes with the environment (Lima et al., 2018; Zhao, 2019).

Chlorella has several applications in agronomic area. For this reason, it has been widely studied new lines of research, such as the development of structural biofilms, for coating of fruit during post-harvest phase. The recent interest in the development of components that increase fruit shelf life has grown once fruits are plant extensions, and respond to the applications of biomasses on their surfaces (Teodosio et al., 2018b). It is important to know the mechanisms of coating biofilm interaction, with fruit peel, and the benefits conferred to the internal part, such as raise in the level of bioactive compounds and quality preservation (Oliveira et al., 2018; Silva et al., 2019a).

Coatings based on biopolymers are fragile, brittle and have low mechanical, thermal and barrier properties, so it becomes necessary to incorporate materials to improve the properties of these coatings (Cano Embuena et al., 2017; Zhao, 2019). Thus, the development of edible functional coatings with active ingredients, such as pomegranate seed oil, represents a 
technological alternative for the agroindustry (Santagata et al., 2018; Teodosio et al., 2018a).

Pomegranate seed oil (PSO) has bioactive lipids, mainly linolenic acid, in the range of $74-85 \%$ of total fatty acid content (Verardo et al., 2014). PSO has already been used as an ingredient in edible coatings and it has shown satisfactory results when associated with biopolymers (Teodosio et al., 2018a; Morais et al., 2020). In this context, the present work aimed to evaluate the post-harvest life of $S$. tuberosa submitted to different coating formulations based on Chlorella sp. associated with pomegranate seed oil, to establish the one that best maintains post-harvest quality.

\section{Materials and methods}

\subsection{Edible coatings}

Coatings were prepared according to Oliveira et al. (2018), with modifications. Chlorella sp. was produced according to Lima (2016), in organic production tanks, at Fazenda Tamanduá (Patos, Brazil). The pomegranate seed oil was extracted according to Silva (2009) at the Federal University of Campina Grande (Pombal, Brazil). Chlorella sp. was diluted in $1 \mathrm{~L}$ of distilled water, under constant stirring, until the solution was completely homogenized and then added with $0.3 \%$ of pomegranate seed oil according to Teodosio et al. (2018b) for the purpose of emulsifying and maximizing the plasticization properties of the coating.

\subsection{Plant material}

Spondias tuberosa fruits were harvested from orchards in Juazeirinho region, in the state of Paraíba, Brazil. The harvest was done at the commercial stage (mature-green), when fruits had peel color between green and shiny, and then they were transported to the Post-Harvest Technology Laboratory of
UFCG, Pombal Campus. Fruits were immersed in cold and chlorinated water $(200 \mathrm{mg}$ sodium dichloro-s-triazinetrione dihydrate - Sumaveg ${ }^{\circledR}$ ) for $20 \mathrm{~min}$. After drying, they were individually immersed in coating treatments for $1 \mathrm{~min}$ and left to dry at $18{ }^{\circ} \mathrm{C}$. Fruits were then packed in trays and stored in BOD at temperature of $24 \pm 2{ }^{\circ} \mathrm{C}$ with $85 \pm 5 \% \mathrm{RH}$.

\subsection{Experimental design}

The experiment was set in a completely randomized design, in a $5 \times 6$ factorial scheme, with four coatings based on Chlorella sp. associated with pomegranate seed oil and the control $(\mathrm{T} 2=0.5 ; \mathrm{T} 3=1.0 ; \mathrm{T} 4=1.5$ e $\mathrm{T} 5=2.0 \%$; and $\mathrm{T} 1=$ control $)$ and six times $(0 ; 1 ; 2 ; 3 ; 4$ e 5 days). The experimental unit comprised ten fruits, and each treatment had three replicates (trays), totaling 900 fruits. Fruits were pulped every evaluation period in order to remove the core using stainless steel knife and later they were processed in domestic centrifuge. Photos were also taken on the last day of storage to demonstrate overall appearance (Figure 1).

\subsection{Analysis of bioactive compounds}

- Vitamin C (mg/100 g ascorbic acid): determined by titration in $1 \mathrm{~mL}$ of diluted juice for $49 \mathrm{~mL}$ of oxalic acid, titration under constant stirring with DFI (2,6-dichlorophenol indophenol) solution. The results were expressed as $\mathrm{mg} / 100 \mathrm{~g}^{-1} \mathrm{~mL}$ FW of ascorbic acid, according to Tillman's method (Association of Official Analytical Chemists, 2012);

- Carotenoids: estimated as described by Lichtentháler (1987). The samples were read in UV-Vis spectrophotometer (Novainstruments, Serie 1600, Brazil) at wavelengths of 470, 646 and $663 \mathrm{~nm}$, once concentrations of chlorophylls $a$ and $b$ must be used to determine carotenoids. The results were expressed in $\mathrm{g} .100 \mathrm{~g}^{-1} \mathrm{FW}$ of the pulp;

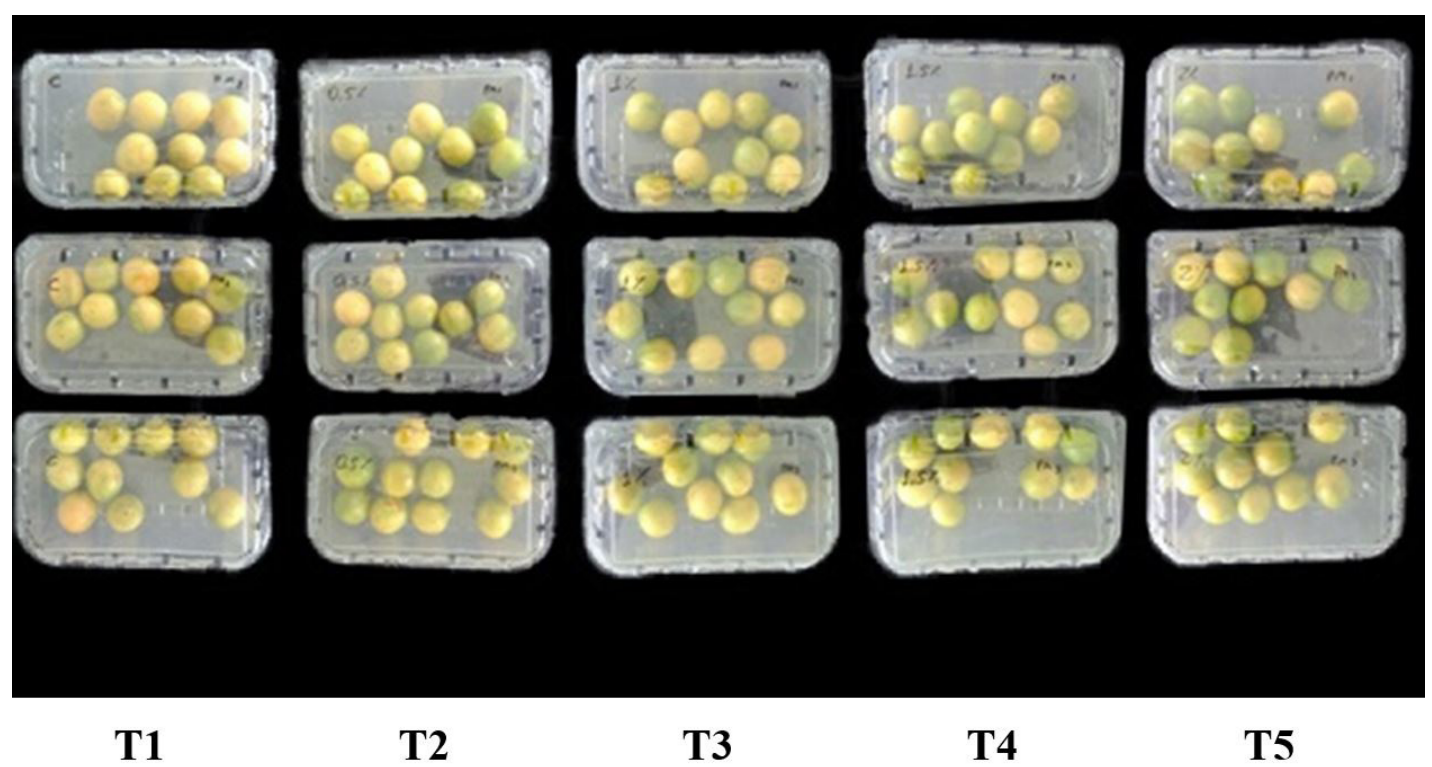

Figure 1. Spondias tuberosa coated with Chlorella sp. associated with PSO stored for 5 days at $24{ }^{\circ} \mathrm{C}$ and $85 \% \mathrm{RH} .(0.0=\mathrm{T} 1 \mathrm{control} ; 0.5 \%=\mathrm{T} 2$; $1.0 \%=\mathrm{T} 3 ; 1.5 \%=\mathrm{T} 4 ; 2.0=\mathrm{T} 5)$. 
- Total phenolic content: measured according to the Folin-Ciocalteau method described by University of California (2012), with modifications. The extracts were prepared from $1 \mathrm{~mL}$ of sample, diluted in $50 \mathrm{~mL}$ of distilled water and allowed to stand for 30 minutes. $800 \mu \mathrm{L}$ aliquot of the extract was transferred to test tube containing $1.325 \mu \mathrm{L}$ of water and $125 \mu \mathrm{L}$ of the folin-Ciocalteau reagent. The mixture was allowed to stand for 5 minutes and then $250 \mu \mathrm{L}$ of $20 \%$ sodium carbonate was added, followed by stirring and standing in water bath at $40^{\circ} \mathrm{C}$ for 30 minutes. The samples were read in UV/Vis spectrophotometer (Novainstruments, Serie 1600, Brazil) at wavelength $765 \mathrm{~nm}$. The results were expressed as mg of gallic acid $100 \mathrm{~g}^{-1} \mathrm{FW}$;

- Soluble sugars: estimated as described by Yemm \& Willis (1954), with modifications. This variable was determined from $1 \mathrm{~mL}$ of juice diluted in $150 \mathrm{~mL}$ of distilled water, from this solution, it was taken $100 \mu \mathrm{L}$ and then it was diluted again in $50 \mathrm{~mL}$ of distilled water. From this last dilution, $1.0 \mathrm{~mL}$ was used for the dosage of anthrone method. The samples were read in UV-Vis spectrophotometer (Novainstruments, Serie 1600, Brazil) at wavelength $620 \mathrm{~nm}$. The results were expressed as g of glucose $100 \mathrm{~g}^{-1} \mathrm{FW}$.

\subsection{Statistical analysis}

Data were submitted to analysis of variance (ANOVA), and the determination of regression coefficients and response surfaces were performed using the software Statistica 7.0 (StatSoft, 2004).

\section{Results and discussion}

The variables of phenolic compounds and total sugars had significant interaction among the factors under study (recoating and storage time), whereas the variables of vitamin $\mathrm{C}$ and carotenoid had significant effect among the analyzed factors (recoating and storage time) but in isolated form (Table 1).

Vitamin C content decreased gradually during storage and this reduction was significantly retarded in all coated fruits (T2, T3, T4 and T5) presenting estimated values of $7.8 ; 8.8 ; 9.6$ and $10.2 \mathrm{mg} .100 \mathrm{~g}^{-1}$, respectively, and control treatment (T1) had the lowest value of $6.5 \mathrm{mg} .100 \mathrm{~g} \mathrm{~g}^{-1}$ during the storage period (Figure 2). It is possible that fruit exposure to abiotic conditions ( $\mathrm{pH}$, temperature, light, oxygen, etc.) during the conservation period contributed to the reduction of this content (Silva et al., 2019b). The highest retention of vitamin C in Spondias tuberosa coated with Chlorella sp. may occur due to low oxygen penetration in coated fruits, which resulted in inhibition of enzymatic activities and, consequently, in reduction of oxidation of vitamin C (Kumar et al., 2017).

Results showed $\mathrm{T} 5$ coating was the most effective to retard the oxidation process in $S$. tuberosa, maintaining higher levels of vitamin C during storage. Similar results were found by Onias et al. (2016) and Oliveira et al. (2018), both with 'Tommy Atkins' mango coated with Spirulina platensis and Chlorella sp.

Regardless of the treatment, carotenoid contents in S. tuberosa increased gradually during the storage period (Figure 3), mainly because there was an evolution in maturation and, therefore, color development. Changes in peel color of fruits, with or without coatings, may have been caused by a peak in ethylene production, which promoted increase in the activity of the chlorophyllase enzymes responsible for degradation of chlorophyll, and induced the synthesis of new enzymes responsible for biosynthesis of carotenoids (Forato et al., 2015).

There was no influence of Chlorella sp. concentrations for carotenoid content in "umbu" fruits. When matured, carotenoid
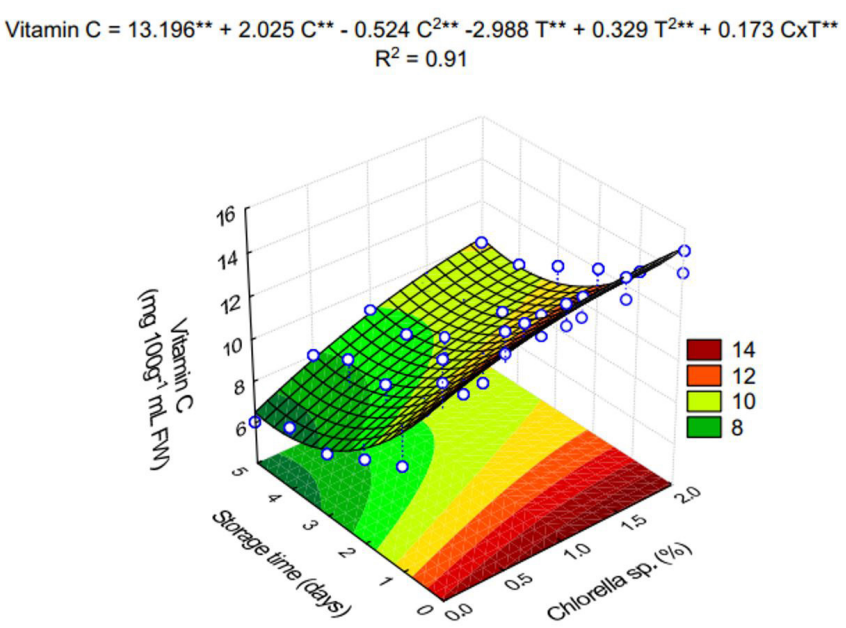

Figure 2. Effect of coatings based on Chlorella sp. associated with PSO on vitamin C of Spondias tuberosa stored for 5 days at $24{ }^{\circ} \mathrm{C}$ and $85 \%$ RH. $0.0=\mathrm{T} 1$ control; $0.5 \%=\mathrm{T} 2 ; 1.0 \%=\mathrm{T} 3 ; 1.5 \%=\mathrm{T} 4 ; 2.0=\mathrm{T} 5$.

Table 1. Summary of variance analysis (ANOVA) of regression models for the effect of vitamin C, carotenoids, phenolic compounds and total sugars in Spondias tuberosa with and without the application of edible coatings stored at $14 \pm 2{ }^{\circ} \mathrm{C}, 85 \pm 5 \% \mathrm{RH}$.

\begin{tabular}{|c|c|c|c|c|c|}
\hline \multirow{2}{*}{ Source of Variation } & \multirow{2}{*}{ DF } & \multicolumn{4}{|c|}{ Middle Square } \\
\hline & & Vitamin C & Carotenoids & Phenolic Compounds & Total Sugars \\
\hline Chlorella (L) & 1 & $20.167^{\star \star}$ & $0.365^{\mathrm{ns}}$ & $333.90^{* *}$ & $28.162^{\star *}$ \\
\hline Chlorella (Q) & 1 & $9.643^{\star *}$ & $3.548^{\star *}$ & $225.40^{\star *}$ & $7.627^{\star *}$ \\
\hline Time (Q) & 1 & $6.997^{\star *}$ & $0.608^{\mathrm{ns}}$ & $312.30^{* *}$ & $1.396^{* *}$ \\
\hline Chlorella $(\mathrm{L}) \times$ Time $(\mathrm{L})$ & 1 & $1.203^{\mathrm{ns}}$ & $0.333^{\text {ns }}$ & $57.59^{* *}$ & $1.763^{\star *}$ \\
\hline
\end{tabular}

$\mathrm{L}=$ Linear regression; $\mathrm{Q}=$ Quadratic regression; ${ }^{* *},{ }^{*},{ }^{\mathrm{ns}}$, significant at $1 \%$, significant at $5 \%$ and not significant, respectively. 
content may vary from 1.5 to $10.0 \mathrm{mg} .100 \mathrm{~g}^{-1}$ (Lima et al., 2018). Melo \& Andrade (2010), evaluating the bioactive compounds in $S$. tuberosa fruits, reported that carotenoids increase during

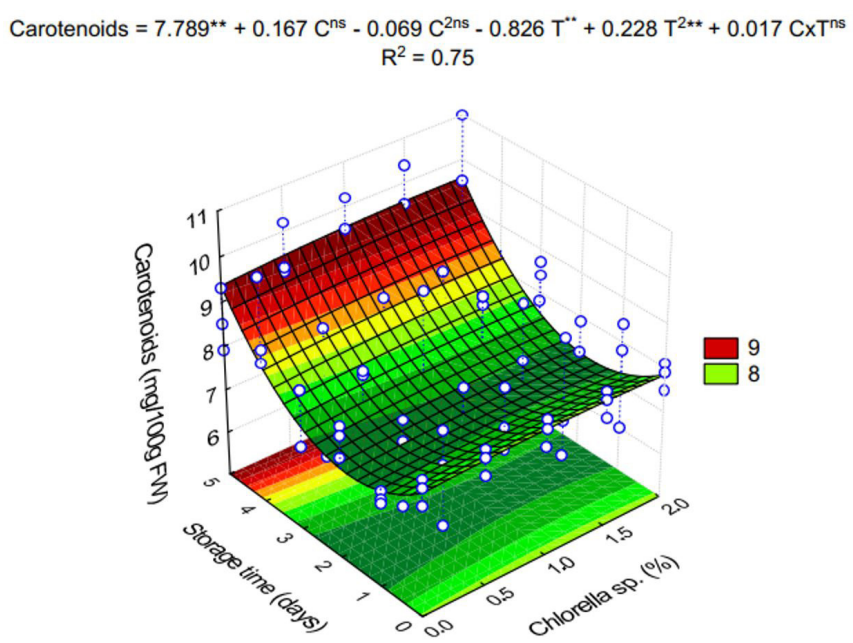

Figure 3. Effect of coatings based on Chlorella sp. associated with PSO on Carotenoids of Spondias tuberosa stored for 5 days at $24{ }^{\circ} \mathrm{C}$ and $85 \%$ RH. $0.0=\mathrm{T} 1$ control; $0.5 \%=\mathrm{T} 2 ; 1.0 \%=\mathrm{T} 3 ; 1.5 \%=\mathrm{T} 4 ; 2.0=\mathrm{T} 5$.

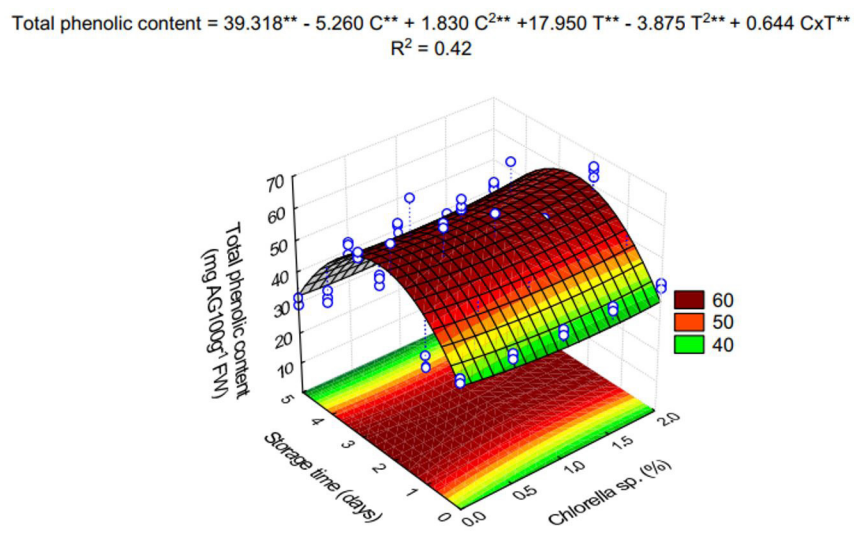

Figure 4. Effect of coatings based on Chlorella sp. associated with PSO on Total phenolic content of Spondias tuberosa stored for 5 days at $24{ }^{\circ} \mathrm{C}$ and $85 \%$ RH. $0.0=\mathrm{T} 1$ control; $0.5 \%=\mathrm{T} 2 ; 1.0 \%=\mathrm{T} 3 ; 1.5 \%=\mathrm{T} 4 ; 2.0=\mathrm{T} 5$. Total soluble sugars $=6.921^{\star \star}-0.434 C^{n s}-0.115 C^{2 n s}+0.783 T^{\star \star}-0.280 T^{2 \star *}+0.097 C x T^{\star \star}$
$R^{2}=0.49$

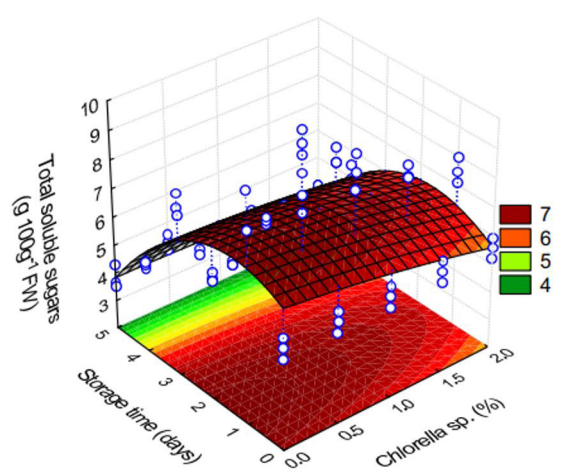

Figure 5. Effect of coatings based on Chlorella sp. associated with PSO on total soluble sugars of Spondias tuberosa stored for 5 days at $24^{\circ} \mathrm{C}$ and $85 \%$ RH. $0.0=$ T 1 control; $0.5 \%=\mathrm{T} 2 ; 1.0 \%=\mathrm{T} 3 ; 1.5 \%=\mathrm{T} 4 ; 2.0=\mathrm{T} 5$. maturation, finding lower values for semi-mature fruits of $1.70 \mathrm{mg} .100 \mathrm{~g}^{-1}$ than mature reaching $3.02 \mathrm{mg}^{1} 100 \mathrm{~g}^{-1}$.

The content of phenolic compounds increased throughout storage, peaked after around three days of storage, and then gradually decreased for coated and non-coated samples on the last day of storage (Figure 4). Kumar et al. (2017) reported the same trend regarding phenolic compounds in chitosan-coated plums.

At the end of five days of storage, the reduction in total phenolic compounds was more pronounced in samples coated with T2 and T3, and also in T1 (control). Samples with T4 and T5 coatings presented the highest levels and it may be attributed to delayed senescence of coated fruits. The phenolic reduction after the fourth day may be a result of the decrease in sugar levels, which inhibit the metabolic pathway of their synthesis (Formiga et al., 2019). Melo \& Andrade (2010), evaluating the bioactive compounds in "umbuzeiro" fruits, reported that phenolic compounds in semi-mature fruits were $38.03 \mathrm{mg} .100 \mathrm{~g}^{-1}$, while in mature this number was $32.70 \mathrm{mg} .100 \mathrm{~g}^{-1}$, and no significant difference was detected among maturation stages of fruits.

There was initial increase for total sugars in S. tuberosa fruits, which must be related to the increases occurred for carotenoids and also maturation process, followed by a gradual decline. On the last day of storage, the reduction in total sugars was more degraded and it must be attributed to the progression of ripening, which soluble sugars started to be metabolized at high rates to support the initial senescence processes in coated fruits (T2, T3, T4, T5) and non-coated fruits (T1) showing estimated values of 3,$8 ; 3.8$;

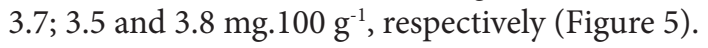

There is great energy demand in the cellular system of $S$. tuberosa fruits to continue the intense metabolic processes during maturation, such as the hydrolysis of starch and other polysaccharides and consequent increase in content of sugars, besides other componentes, as flavor which is responsible for the sweet-acidulated taste of this exotic fruit. Dantas (2008), evaluating fruit quality for 32 genotypes of $S$. tuberosa from the Northeastern semi-arid region, verified variation of more than double from 3.6 to $8.31 \mathrm{mg} .100 \mathrm{~g}^{-1}$ for total sugars, which possibly this amplitude in the content of total sugars must be attributed to the genetic variability of the materials.

\section{Conclusion}

Coatings using Chlorella sp. associated with pomegranate seed oil (PSO) had positive effect on the conservation of Spondias tuberosa, prolonging shelf life of fruits. The treatment $2.0 \%$ Chlorella sp. associated with PSO was able to preserve the content of vitamin $\mathrm{C}$ and phenolic compounds, thus presenting the best results in the maintenance of fruit quality.

\section{References}

Albuquerque, E. M. B., Almeida, F. A. C., Gomes, J. P., Alves, N. M. C., \& Silva, W. P. (2015). Production of "peanut milk" based beverages enriched with umbu and guava pulps. Journal of the Saudi Society of Agricultural Sciences, 14(1), 61-67. http://dx.doi.org/10.1016/j. jssas.2013.07.002. 
Association of Official Analytical Chemists - AOAC. (2012). Official methods of analysis of the Association of Official Analytical Chemists (19th ed.). Gaithersburg: AOAC.

Cano Embuena, A. I., Cháfer Nácher, M., Chiralt Boix, A., Molina Pons, M. P., Borrás Llopis, M., Beltran Martínez, M. C., \& González Martínez, C. (2017). Quality of goat's milk cheese as affected by coating with edible chitosan-essential oil films. International Journal of Dairy Technology, 70(1), 68-76. http://dx.doi.org/10.1111/1471-0307.12306.

Ciolacu, L., Nicolau, A. L., \& Hoorfar, J. (2014). Edible coatings for fresh and minimally processed fruits and vegetables. Global Safety of Fresh Produce, 1(1), 233-244. http://dx.doi.org/10.1533/9781782420279.3.233.

Dantas, O. R., Jr. (2008). Qualidade e capacidade antioxidante total de frutos de genótipos de umbuzeiro oriundos do semi-árido nordestino (Tese de doutorado). Universidade Federal da Paraíba, Areia.

Dias, J. L., Mazzutti, S., De Souza, J. A. L., Ferreira, S. R. S., Soares, L. A. L., Stragevitch, L., \& Danielski, L. (2019). Extraction of umbu (Spondias tuberosa) seed oil using CO2, ultrasound and conventional methods: evaluations of composition profiles and antioxidant activities. The Journal of Supercritical Fluids, 145(3), 10-18. http://dx.doi.org/10.1016/j. supflu.2018.11.011.

Forato, L. A., Britto, D., Rizzo, J. S., Gastaldi, T. A., \& Assis, O. B. G, (2015). Effect of cashew gum-carboxymethylcellulose edible coatings in extending the shelf-life of fresh and cut guavas. Food Packaging and Shelf Life, 5(3), 68-74. http://dx.doi.org/10.1016/j.fpsl.2015.06.001.

Formiga, A. S., Pinsetta, J. S., Pereira, E. M., Cordeiro, I. N. F., \& Mattiuz, B.-H. (2019). Use of edible coatings based on hydroxypropyl methylcellulose and beeswax in the conservation of red guava 'Pedro Sato. Food Chemistry, 290, 144-151.http://dx.doi.org/10.1016/j.foodchem.2019.03.142. PMid:31000030.

Giovannoni, J., Nguyen, C., Ampofo, B., Zhong, S., \& Fei, Z. (2017). The epigenome and transcriptional dynamics of fruit ripening. Annual Review of Plant Biology, 68(1), 61-84. http://dx.doi.org/10.1146/annurevarplant-042916-040906. PMid:28226232.

Kumar, P., Sethi, S., Sharma, R. R., Srivastav, M., \& Varghese, E. (2017). Effect of chitosan coating on postharvest life and quality of plum during storage at low temperature. Scientia Horticulturae, 226(13), 104-109.

Lichtentháler, H. K. (1987). Chlorophylls and carotenoids: pigments of photosynthetic biomembranes.). Methods in Enzymology, 148(1), 350382. http://dx.doi.org/10.1016/0076-6879(87)48036-1.

Lima, J. F. (2016). Cultivo e secagem da microalga Chlorella sp. em diferentes concentrações de nutrientes (Tese de doutorado). Universidade Federal de Campina Grande, Campina Grande.

Lima, M. A. C., Silva, S. M., \& Oliveira, V. R. (2018). Umbu - Spondias tuberosa. Exotic Fruits, 1(1), 427-433. http://dx.doi.org/10.1016/B9780-12-803138-4.00057-5.

Lorenzi, H., Lacerda, M. T. C., \& Bacher, L. B. (2015). Frutas no Brasil nativas e exóticas: de consumo in natura. São Paulo: Instituto Plantarum de Estudos da Flora.

Maringgal, B., Hashim, N., Tawakkal, I. S. M. A., \& Mohamed, M. T. M. (2020). Recent advance in edible coating and its effect on fresh/fresh-cut fruits quality. Trends in Food Science \& Technology, 96(2), 253-267. http:// dx.doi.org/10.1016/j.tifs.2019.12.024.

Melo, E. A., \& Andrade, R. A. M. S. (2010). Compostos bioativos e potencial antioxidante de frutos do umbuzeiro. Alimentos e Nutrição, 21(3), 453-457. Retrieved from http://serv-bib.fcfar.unesp.br/seer/index.php/alimentos/ article/view/1208/1208

Morais, F. A. D., Araújo, R. H. C. R., Oliveira, A. M. F. D., Alves, K. D. A., Vitor, R. C. L., Morais, S. K. Q., Teodosio, A. E. M. M., Onias, E. A., \& Oliveira, A. G. D. (2020). Agar and pomegranate seed oil used in a biodegradable coating composition for Formosa papaya. Food Science and Technology. In press. http://dx.doi.org/10.1590/fst.10119.

Moura, F. T., Silva, S. M., Schunemann, A. P. P., \& Martins, L. P. (2013). Frutos do umbuzeiro armazenados sob atmosfera modificada e ambiente em diferentes estádios de maturação. Ciência Agronômica, 44(4), 764-772. http://dx.doi.org/10.1590/S1806-66902013000400013.

Oliveira, A. M. F., Rocha, R. H. C., Guedes, W. A., Dias, G. A., Lima, J. F., Oliveira, L. M., Alves, K. A., Teodosio, A. E. M. M., \& Morais, F. A. (2018). Postharvest of "Tommy Atkins" mango submitted to coating of Chlorella sp. The Journal of Agricultural Science, 10(9), 225-233. http:// dx.doi.org/10.5539/jas.v10n9p225.

Onias, E. A., Rocha, R. H. C., Lima, J. F., Onias, E. A., \& Furtunato, T. C. S. (2016). Qualidade pós-colheita de manga "Tommy Atkins"e orgânica tratada com biofilmes enriquecidos com Spirulina platensis. Científica, 44(3), 286-293. http://dx.doi.org/10.15361/1984-5529.2016v44n3p286-293.

Ribeiro, L. O., Pontes, S. M., Ribeiro, A. P. O., Pacheco, S., Freitas, S. P., \& Matta, V. M. (2017). Avaliação do armazenamento a frio sobre os compostos bioativos e as características físico-químicas e microbiológicas do suco de umbu pasteurizado. Brazilian Journal of Food Technology, 20(3), 1-8. http://dx.doi.org/10.1590/1981-6723.9515.

Santagata, G., Mallardo, S., Fasulo, G., Lavermicocca, P., Valerio, F., Di Biase, M., Di Stasio, M., Malinconico, M., \& Volpe, M. G. (2018). Pectin-honey coating as novel dehydrating bioactive agent for cut fruit: enhancement of the functional properties of coated dried fruits. Food Chemistry, 258(20), 104-110. http://dx.doi.org/10.1016/j.foodchem.2018.03.064. PMid:29655710.

Silva, I.C.C. (2009). Uso de processos combinados para o aumento do rendimento da extração e da qualidade do óleo de macaúba (Dissertação de mestrado). Universidade Federal do Rio de Janeiro, Rio de Janeiro.

Silva, J., Alves, C., Pinteus, S., Reboleira, J., Pedrosa, R., \& Bernardino, S. (2019a). Chlorella. In S. M. Nabavi \& A. S. Silva (Eds.), Nonvitamin and nonmineral nutritional supplements (pp. 187-193). London: Academic Press. http://dx.doi.org/10.1016/B978-0-12-812491-8.00026-6.

Silva, V. P., Paz, M. A., Souza, K. S. M., \& Abreu, A. K. F. (2019b). Qualidade pós-colheita de frutos de umbuzeiro (Spondias tuberosa Arr.) embalados com filme de pvc. Revista Craibeiras de Agroecologia, 4(1), e7714. Retrieved from http://www.seer.ufal.br/index.php/era/article/view/7714/5585

StatSoft. (2004). Statistica (data analysis software system), version 7. Tulsa.

Teodosio, A. E. M. M., Onias, E. A., Oliveira, L. M., Rodrigues, M. H. B. S., Ribeiro, J. A., Queiroga, T. B., Mesquita, E. F., Araújo, R. H. C. R., \& Santos, B. G. F. L. (2018a). Influence of different coatings on quality and shelflife of guava under different storage temperatures. Journal of Experimental Agriculture International, 26(3), 1-10. http://dx.doi. org/10.9734/JEAI/2018/43852.

Teodosio, A. E. M. M., Rocha, R. H. C., Lima, J. F., Onias, E. A., Ferreira, A. P. N., Santos, B. G. F. L., Rodrigues, M. H. B. S., Oliveira, L. M., Oliveira, A. M. F., Medeiros, M. L. S., \& Silva, K. G. (2018b). Effect of the biodegradable coatings the base on microalgae and oil of the seed of the pomegranate in the conservation powder-crop of the papaya 'golden'. The Journal of Agricultural Science, 10(10), 367-377. http://dx.doi.org/10.5539/jas. v10n10p367.

University of California, Waterhouse Lab. (2012). Folin-Ciocalteu micro method for total phenol in wine. Davis. Retrieved from http://waterhouse. ucdavis.edu/phenol/folinmicro.htm

Verardo, V., Garcia-Salas, P., Baldi, E., Segura-Carretero, A., Fernandez-Gutierrez, A., \& Caboni, M. F. (2014). Pomegranate seeds as a source of nutraceutical oil naturally rich in bioactive lipids. Food Research International, 65(15), 445-452. http://dx.doi.org/10.1016/j.foodres.2014.04.044.

Yemm, E. W., \& Willis, A. J. (1954). The estimation of carbohydrates in plant extracts by anthrone. The Biochemical Journal, 57(3), 508-514. http:// dx.doi.org/10.1042/bj0570508. PMid:13181867.

Zhao, Y. (2019). Edible coatings for extending shelf-life of fresh produce during postharvest storage. Encyclopedia of Food Security and Sustainability, 2(1), 506-510. http://dx.doi.org/10.1016/B978-0-08-100596-5.22262-2. 